\title{
Public Expenditure and Agricultural Production in Meghalaya, India: An Application of Bounds Testing Approach to Co-Integration and Error Correction Model
}

\author{
Utpal Kumar De* and Dahun S Dkhar \\ Department of Economics, North-Eastern Hill University, India
}

Submission: December 19, 2017; Published: January 16, 2018

*Corresponding author: Utpal Kumar De, Department of Economics, North-Eastern Hill University, Shillong, 793022, Meghalaya, India, Tel: +91364-2723182 (0); +91-364-2726182 (R); +91-9436102 066 (M); Email: utpalkde@gmail.com; de u@yahoo.com

Abstract

An attempt is made in this paper to examine the short and long run relationship between government expenditure on agriculture and its allied sector and agricultural output of Meghalaya. The study is based on a time series data of 30 years from 1984-85 to 2013-14. During this period, the state economy has experienced both upswing and downswing in its agricultural sector. Government expenditure in different sectors including agriculture and its allied activities, education, transport etc is expected to promote agricultural production. Here ARDL approach to co integration and an error correction representation of the ARDL model have been used due to certain advantages. The result of the Bounds test indicates the presence of a long-run co integrating relationship between the variables in the study. The results reveal that in the long run, the effect of public expenditure through agriculture and allied activities, on agricultural output is significantly negative, while expenditures on education and transport on agricultural output are significantly positive that is in line with several earlier studies. Public expenditure in healthcare however does not significantly affect agricultural output. The findings reveal that judicious use of government spending have significant potential to accelerate agricultural development and improve its efficiency.

Keywords: Public Expenditure in Agriculture; Agricultural Growth; Bounds Test; ARDL; Co-Integration; Meghalaya

Abbreviations: GSDP: Gross State Domestic Product; TE: Total Expenditure; TGA: Total Government Expenditure on Agriculture; FMOLS: Fully Modified Ordinary Least Square; ADF: Augmented Dickey Fuller Test; ARDL: Autoregressive Distributed Lag; SBC: Schwarz Bayesian Criterion; AIC: Akaike Information Criterion; CUSUM: Cumulative Sum of Recursive residuals; CUSUMQ: Cumulative Sum of Squares of Recursive Residuals

\section{Introduction}

Finance is an essential need of any country whether developed or developing. A government needs to gather resources in an adequate and proper way; and apportion and utilize resources or assets responsively, productively and successfully [1]. Public expenditure is alluded to as an outpouring of assets from government to different areas of the economy [2]. It is in fact the main instrument for a government to control the economy to bring about economic growth, which in turn promotes the living standard of people by providing better infrastructure, good health, education, an improvement in agricultural output and food security [3]. Expenditure in agriculture is important for the transformation of agricultural sector that is more important for an agricultural economy [4]. Low agricultural output has a negative effect on the economy as a whole vide its low production of food and raw materials for industries. It therefore follows that in economies where majority of the population depends on agriculture for its livelihood, government agricultural spending is one of the most important instruments of government for promoting overall economic development and the alleviation of poverty. Agricultural spending by the Government can directly increase agricultural output by shifting upward the production frontier as in the case of irrigation [5]. It therefore implies that agricultural spending by the Government increases the rate of return to private agricultural investment and thereby leads to greater investment and output in the agricultural sector of the economy.

\section{The Problem and Objective}

Government spending can specifically or indirectly influence farm income. Government spending that is correlative to private investments would to some degree influence productivity of farming sector. Public expenditure like access or provision of credit to farmers, spending on animal health, veterinary, research, extension services and access to roads in rural areas has a significant effect on the output of the agricultural sector. In Meghalaya, a key challenge for the government has been to increase productivity of all agriculture and horticulture crops in the state so as to keep pace with the growing need of population. 
However, efforts on the part of agriculture sector have not yet produced the desired outcome. Therefore the question arises if public expenditure in the state has any significant and positive impact on the agriculture output in Meghalaya. This study therefore is an attempt to investigate the direction and magnitude of relationship between public expenditure in agriculture and agricultural output in Meghalaya. With the above problem at hand, we tried to analyze the existence of long run relationship between public expenditure and agriculture output in Meghalaya. It also exposed the contribution of government budgetary allocation to the agriculture sector in Meghalaya.

\section{Background of the study}

Meghalaya, a state in North-East India has predominantly an agrarian economy. The importance of the agriculture sector in the state economy can be seen from the percentage of working population engaged in this sector. In 2011, percentage of working population engaged in agriculture was 58.4 percent and in 2001 it ass 65.8 percent. Agriculture still continues to employ majority of workers in the state although there has been a decline in proportion of workers engaged in agriculture. As per 2011 census, there has been a marginal fall in rural population since 2001 from 80.4 percent (2001) to 79.9 percent (2011). Although the rural population has declined, level of urbanization is still low with urban population increasing marginally from 19.58 percent in 2001 to 20.06 percent of total population in 2011. The economy of the state is relative small as compared to other states in the country. According to estimates of the state government, gross state domestic product (GSDP) in 2011-12 at current prices was Rs. 16434 crore while GSDP at constant (2004-05) prices was Rs. 11141 crore. From 2002-03 to 2011-12 the state GSDP (at constant 2004-05 prices) grew at an average annual growth rate of 7.9 percent. The total expenditure in agriculture sector stood at Rs. 14431.26 lakhs in 1984-85 and increased to Rs 38679.46 lakhs in 2013-14 (at constant 200405 prices). Despite increase in expenditure on the agriculture sector, the contribution of this sector to real GSDP declined from $7.29 \%$ in $1984-85$ to $2.90 \%$ in $2013-14$. However, from the perspective of rural livelihood, agriculture remains an important economic sector, despite its declining share in GDP. Since a large part of population is employed in farming, financial development is practically difficult to accomplish without building up the sector. Research on this issue is therefore essential to help policy decisions with regards to proper allocation of public expenditure and its proper spending to accomplish agricultural growth and development.

The share of public expenditure (three years moving average) through Agriculture and allied activities, Education, Medical and Public Health, Rural development, Transportation and Communication as a percentage of Total Expenditure (TE) is presented in (Figure 1) at constant 2004-05 prices. The share remained almost constant during the period of 1984-87 to 200003 but decreased the next year and then again remained almost constant from 2002-05 onwards till. The share of Transport and Communication expenditure as a percentage of total expenditure initially decreased and then gradually increases upto 1994-97 and gradually decreased up to 2000-03 and then drifted down sharply but from 2001-04 it remained almost constant for the remaining study period. Public expenditure through agriculture and allied activities as a percentage of total expenditure also followed a similar trend. During the study period, the average share of public expenditure on medical and public health, transport and communication, agriculture and allied activities and education as a percentage of the total expenditure were $2.66,4.29,7.03,7.65$ and10.69.

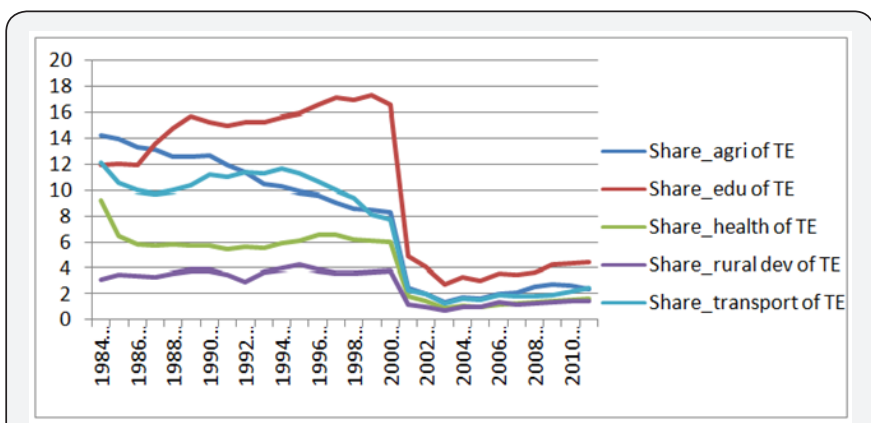

Figure 1: Share of Public expenditure on Agriculture and allied activities (agri), Education (edu), Medical \& Public Health (health), Rural development (rural dev), Transportation and Communication (transport) as a percentage of Total Expenditure (TE).

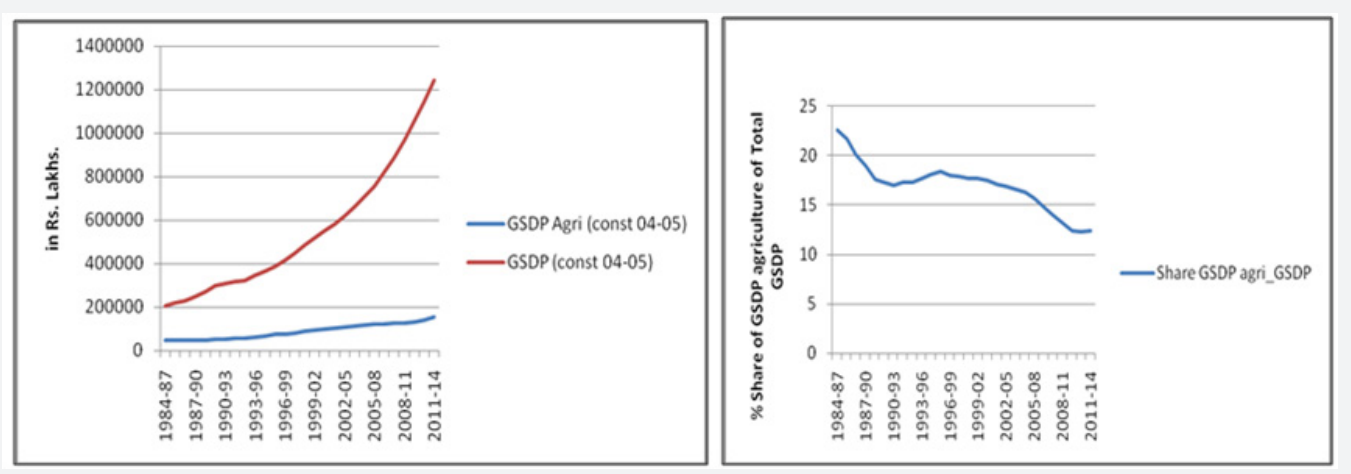

Figure 2 (a) and (b): Trends of Gross State Domestic Product of Agriculture (GSDP Agri), Total Gross State Domestic Product (GSDP) and percentage share of GSDP Agriculture to GSDP (3 years moving average). 
From (Figure 2a), we can see that both GSDP agriculture and GSDP of Meghalaya exhibit an increasing trend over the years (in Rs. Lakhs). However, percentage share of GSDP agriculture to total GSDP of Meghalaya decreased over the years (Figure $2 \mathrm{~b}$ ) with the highest percentage share of 22.56 and the lowest percentage share of 12.32. The average percentage share GSDP agriculture to overall GSDP was 16.91. Production of principle crops over the years in Meghalaya is depicted in (Figure 3). The crops have been categorized into food grains, oilseeds, fruit crops, tuber crops, spice crops, plantation and other crops. We can see that the production of different categories of crop groups followed increasing trend. Total food grain has been at the top with an average production of - 25MT during the study period, which was followed by tuber crops with an average production of 193529 MT and fruits with an average production of 176584 MT. Sugarcane and tobacco was at the lowest in terms of production with an average figure of 774 MT during the study period.

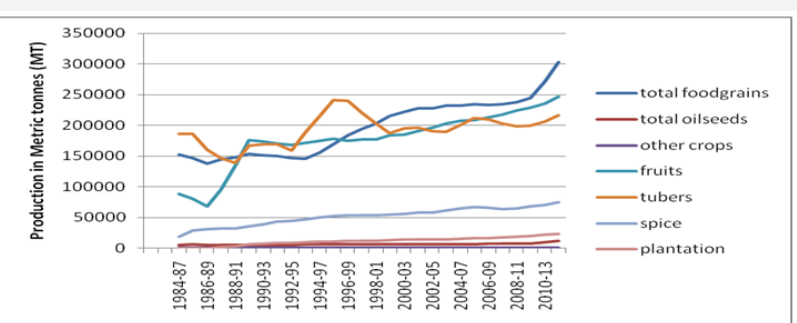

Figure 3: Production of crop groups in Meghalaya over the years.

\section{Review of literature}

Public expenditure plays an important role in the functioning of economy at almost all phases of economic advancement. The government resorts to expenditure and programs to produce desirable results on the national income and employment generation. A number of studies reveal that there is a positive relationship between public expenditure and agriculture output [6-8]. On the other hand, some studies show a negative relationship between public expenditure and agriculture output [9-12]. Public investment in R \& D is observed to be a superior performer in enhancing agricultural results and decreasing poverty or destitution. Analyzing the returns on different types of investment in agriculture i.e., irrigation, extension, resulted in mixed outcomes and in aggregate public investments in agriculture resulted in modest outcome. Since, the impact of different investments in agriculture vary in magnitude, the returns on agricultural public spending might also differ according to the commodity being focused [13].

A study on the effects of government budgetary allocation (public expenditure) to agricultural output in Nigeria by Adofu, Abula and Agama [14] using OLS regression found that the major determinant of agricultural output (proxy by agricultural contribution to Real GDP) is budgetary allocation to agricultural sector and credit to the agricultural sector. Both the variablesbudgetary allocation and credit to the agricultural sector has a positive relationship with agricultural output. In their assessment of Nigeria expenditure on the agricultural sector and its relationship with agricultural output shows the existence of a long-run relationship between government expenditure on agriculture (capital and recurrent), and agricultural contribution to GDP (output) [15]. The result from causality shows that a reduction in total government expenditure on agriculture (TGA) has a negative effect on agricultural contribution to GDP (output) in Nigeria. Results also revealed that there is no causality between the variables up to 4 lag lengths at $5 \%$ level of significance. However, at $10 \%$ level of significance and 2 lag lengths TGA is found to granger cause AGDP with no reverse causality from AGDP to TGA. Similarly, at 10\% level of significance and 3 lag lengths, a unidirectional causality running from AGDP to TGA with no reverse causality from TGA to AGDP is found.

Investigate the impact of macroeconomic policy on agricultural output in Nigeria (1978 to 2011) [16]. Result from estimation of the long-run co-integration equation normalized on agricultural output reveal a significant relationship with respect to Government spending, Exchange rate, Agricultural Credit and Inflation rate. The main finding of their investigation is that government spending on agriculture plays a significant role in achieving food security in Nigeria. In their case study on the impact of agricultural public spending on agricultural productivity in Kenya found that there is a positive and significant relationship between agricultural productivity and agricultural donor spending. Also [17] show that agricultural output and public expenditure on agricultural sector has a positive impact on the economic and agricultural growth in Pakistan [18]. In a study on the determinants of agricultural productivity in Kenya, [19] find that there is a negative impact of exchange rate and inflation on agricultural productivity whereas labor force, rainfall, and government expenditure has a positive impact on agricultural productivity in the long run. In the short run labor, rainfall, and government expenditure are the main determinants of agricultural productivity Using Fully Modified Ordinary Least Square (FMOLS) regression in a study on government fiscal policy and agricultural sector outputs in Nigeria, [20] reveals that the value added tax (vat) and government total recurrent expenditure on agriculture has a significant and positive relationship on the growth of agricultural output while total government capital expenditure on agriculture has a negative and insignificant relationship with value of agriculture output.

\section{Materials and Methods}

This study is based on the secondary data for the period 1984-85 to 2013-14. Annual time series data on agricultural GSDP is used as a proxy for agriculture output which is obtained from the Directorate of Economics and Statistics, Meghalaya. The variables pertaining to public expenditure in agriculture and allied activities, education, health, rural development, rural development and transportation are collected from RBI 
Publications of State Finances: A Study of Budgets. To neutralize the impact of increase and decrease of prices, all the time series variables that have been employed for the study are deflated by using GDP (GSDP) deflator and are all expressed in Rupee Lakhs at Constant 2004-05 prices. All the variables in the model are tested for stationary using the Augmented Dickey Fuller Test (ADF Test). The ADF test is conducted using the following regression (1) which includes a trend and an intercept.

$$
\Delta \mathrm{Y}_{\mathrm{t}}=\mathrm{B}_{1}+\mathrm{B}_{2} \mathrm{t}+\mathrm{ZY}_{\mathrm{t}-1}+\sum_{\mathrm{i}=1}^{\mathrm{m}} \mathrm{a}_{\mathrm{i}} \mathrm{Y}_{\mathrm{t}-\mathrm{i}}+\mathrm{e}_{\mathrm{t}} \ldots \ldots \ldots \text { (1) }
$$

Where $\Delta \mathrm{Y}_{\mathrm{t}}$ is the first difference of the series $\mathrm{Y}_{\mathrm{e}} \mathrm{e}_{\mathrm{t}}$ is a stochastic error term and where $\Delta \mathrm{Yt}-1=\left(\mathrm{Y}_{\mathrm{t}-1}-\mathrm{Y}_{\mathrm{t}-2}\right), \Delta \mathrm{Yt}-2=\left(\mathrm{Y}_{\mathrm{t}-2}-\mathrm{Y}_{\mathrm{t}-3}\right)$, etc. $B_{1}$ is a constant, $t$ is the time, $B_{2}$ and $Z$ are parameters. The number of lagged difference terms to include is often determined empirically, the idea being to include enough terms so that the error term in the above equation is serially uncorrelated. The null hypothesis stated that variable has a unit root or variable is not stationary against the alternative hypothesis that variable is stationary.

\section{Model Specification}

The following equation is estimated to investigate the impact of public expenditure on agriculture output

$\operatorname{Ln}($ Gsdpagri $)=\beta_{0}+\beta_{1} \operatorname{Ln}($ Agriexp $)+\beta_{2} \operatorname{Ln}(E d u)+\beta_{3}$ $\operatorname{Ln}($ Health $)+\beta_{4} \operatorname{Ln}($ Rudev $)+\beta_{5} \operatorname{Ln}($ Trans $)$...(1). Here Gsdpagri (proxied for agricultural output) represent the agricultural GSDP. Agriexp, Edu, Health, Rudev and Trans represent the public expenditure on Agriculture and Allied Activities (it includes Crop husbandry, Soil and Water Conservation, Animal Husbandry, Dairy Development, Fisheries, Forestry and Wild Life, Agricultural Research and Education, Agricultural Finance Institutions, Co-operation and Other Agricultural Programmes), Education, Medical and Public Health, Rural Development and Transport and Communications respectively. $\beta_{1}, \beta_{2}, \beta_{3}, \beta_{4}, \beta_{5}$, are the long run elasticities of Gross State Domestic Product of Agriculture with respect to public expenditure on Agriculture and Allied Activities, Education, Medical and Public Health, Rural Development and Transport and Communications respectively.

\section{Bounds Test}

To find out if there is co integration or long-run relationship among the variables under study, bounds testing (or autoregressive distributed lag (ARDL)) co integration procedure developed by [21] is employed. Unlike other co integration test, bounds test is applicable regardless of whether the variables in the model are I(0) or I(1) or a mixture of those. However, the method is not applicable in the presence of I(2) series. Therefore, before employing the Bounds Test we test the level of integration of all the variables of interest by using the ADF Test. In order to find the long-run relationship as given in equation (1), we conduct bounds test of equation (2) using F-statistic with two bounds (lower and upper bound). The null hypothesis assumes no co integration/long-run relationship among the variables of interest. Null hypothesis is rejected if the value of F statistic is greater than the upper bound and it is accepted if the value of $F$ statistic is less than lower bound. However if it the value of $F$ statistic falls between the lower and upper bounds the inference is inconclusive. For testing stationary and co integration, Schwarz Bayesian Criterion (SBC) is used to select the optimal lag length of variables. Autoregressive Distributed Lag (ARDL) model was proposed by [21] and was further extended by [22]. This method is employed in order to capture the long-run as well as the short-run dynamic relationship among the variables. The ARDL model of the relationship between Gross State Domestic Product of Agriculture with respect to public expenditure on Agriculture and Allied Activities, Education, Medical and Public Health, Rural Development and Transport and Communications is represented as follows:

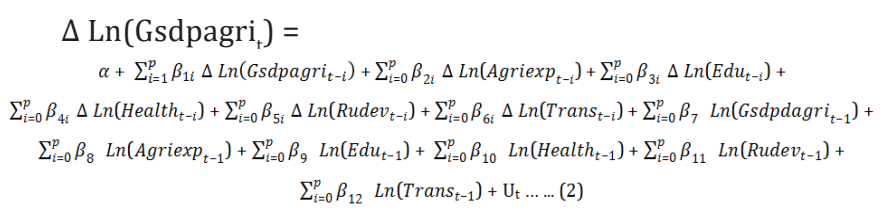

Where $p$ is the optimal lag length, $\beta_{1}, \beta_{2}, \beta_{3^{\prime}}, \beta_{4^{\prime}} \beta_{5}$ and $\beta_{6}$, represent the short run dynamics of the model and $\beta 8, \beta 9, \beta 10$, $\beta_{11}$ and $\beta_{12}$ are the long run elasticities and $U_{t}$ is the error term. The conditional ARDL (p, q1, q2, q3, q4, q5) long-run model is established below:

$\operatorname{Ln}\left(\right.$ Gsdpagri $\left._{t}\right)=\alpha+\sum_{i=1}^{p} \beta_{1} \operatorname{Ln}\left(\right.$ Gsdpagri $\left._{t-i}\right)+\sum_{i=0}^{q 1} \beta_{2} \operatorname{Ln}\left(\operatorname{Agriexp}_{t-i}\right)+\sum_{i=0}^{q 2} \beta_{3} \operatorname{Ln}\left(\operatorname{Edu}_{t-i}\right)+$

$\sum_{i=0}^{q 3} \beta_{4} \operatorname{Ln}_{\text {Health }}$ Hei $\left._{i}\right)+\sum_{i=0}^{q 4} \beta_{5} \operatorname{Ln}\left(\right.$ Rudev $\left._{t-i}\right)+\sum_{i=0}^{q 5} \beta_{6}$ Ln $\left.^{\text {Trans }} t_{-i}\right)+\mathrm{U}_{t} \ldots \ldots \ldots$ (3)

Finally, Short Run Dynamic coefficients are obtained by estimating an error correction model associated with long run estimates. The equation is as follows:

$\Delta \operatorname{Ln}\left(\right.$ Gsdpagri $\left._{t}\right)=\alpha+\sum_{i=1}^{p} \beta_{1} \Delta \operatorname{Ln}\left(\right.$ Gsdpagri $\left._{t-i}\right)+\sum_{i=0}^{q_{1}} \beta_{2} \Delta \operatorname{Ln}\left(\operatorname{Agriexp}_{t-i}\right)+\sum_{i=0}^{q_{2}} \beta_{3} \Delta \operatorname{Ln}\left(E d u_{t-i}\right)+$ $\sum_{i=0}^{q_{3}} \beta_{4} \Delta \operatorname{Ln}\left(\right.$ Health $\left._{t-i}\right)+\sum_{i=0}^{q_{t}} \beta_{5} \Delta \operatorname{Ln}\left(\right.$ Rudev $\left._{t-i}\right)+\sum_{i=0}^{q_{5}} \beta_{6} \Delta \operatorname{Ln}\left(\right.$ Trans $\left._{t-i}\right)+\sum_{i=0}^{q_{5}} \beta_{6} \Delta \operatorname{Ln}\left(\right.$ Trans $\left._{t-i}\right)+$ $\beta_{7} E C T_{t-1}+U_{t} \ldots \ldots$ (4)

\section{Results and Discussion}

\section{Unit Roots Tests}

Stationary of all the variables is tested by Augmented Dickey Fuller (ADF) Test. Absolute value of ADF test statistic of public expenditure variables viz., Agriculture and Allied activities, Education, Transportation and Communication and agricultural GSDP at level are less than the absolute critical values. Therefore the null hypothesis is accepted. This indicates that the time series variables are not stationary at level. As it is well known that the non-stationary data series are poor candidates for reliable regression since they yield spurious results that are useless for predictive purposes. After taking first difference, the absolute value of ADF test statistics of those variables are however greater than the absolute critical values, and thus the null hypothesis is rejected which confirms that the $1^{\text {st }}$ differences of variables are stationary (Table 1). The result of the Bounds test presented in (Table 2) shows that the calculated F-statistics is higher than the critical value at $1 \%$ level of significance of the [23] upper bound 
values. Therefore, the null hypothesis of no co integration is rejected, which signifies the presence of a long-run co integrating relationship among the variables in the study. Since there is long run co integration between the variables in the bounds test, the ARDL approach can now be adopted to estimate the level of relationship. The ARDL model is selected on the basis of the Akaike Information Criterion (AIC). The estimated coefficients of the long-run relationship are shown in (Table 3). In the long run, effect of public expenditure through agriculture and allied activities on agricultural output is significant at $1 \%$ level.

Table 1: Unit Root Test Results.

\begin{tabular}{|c|c|c|c|c|c|c|}
\hline \multirow[b]{2}{*}{ Variable } & \multicolumn{3}{|c|}{ Level } & \multicolumn{3}{|c|}{ First Difference } \\
\hline & $\begin{array}{l}\text { ADF test } \\
\text { statistic }\end{array}$ & Prob & Decision & $\begin{array}{l}\text { ADF test } \\
\text { statistic }\end{array}$ & Prob & Decision \\
\hline Lnagriexp & -0.845 & 0.949 & $\begin{array}{c}\text { Not } \\
\text { Stationary }\end{array}$ & $-4.379 *$ & 0.009 & Stationary \\
\hline Lnedu & -3.184 & 0.109 & $\begin{array}{c}\text { Not } \\
\text { Stationary }\end{array}$ & $-4.722 *$ & 0.004 & Stationary \\
\hline Lnhealth & $-3.467^{* * *}$ & 0.062 & Stationary & & & \\
\hline Lnrudev & $-3.928^{* *}$ & 0.024 & Stationary & & & \\
\hline Lntrans & -1.420 & 0.833 & $\begin{array}{c}\text { Not } \\
\text { Stationary }\end{array}$ & $-6.603^{*}$ & 0.000 & Stationary \\
\hline Lngsdpagri & -2.993 & 0.151 & $\begin{array}{c}\text { Not } \\
\text { Stationary }\end{array}$ & $-7.355^{*}$ & 0.000 & Stationary \\
\hline
\end{tabular}

Table 2: Result obtained by ARDL Bounds Test.

\begin{tabular}{|c|c|c|c|}
\hline \multicolumn{4}{|c|}{ Sample: 1987 - 2014 Included observations: 28} \\
\hline \multicolumn{4}{|c|}{ Null Hypothesis: No long-run relationships exist } \\
\hline Test Statistic & Value & $\mathbf{k}$ & \\
\hline F-statistic & 4.846571 & 5 & \\
\hline \multicolumn{3}{|c|}{ Critical Value Bounds } & \\
\hline Significance & I0 Bound & I1 Bound & \\
\hline $10 \%, 5 \%, 2.5 \%$ and $1 \%$ & $2.26,2.62,2.96,3.41$ & $3.35,3.79,4.18,4.68$ & \\
\hline R2, Adjusted R2, D-Stat & $0.684,0.498,2.206$ & Akaike info criterion & -3.224 \\
\hline Log likelihood & 56.141 & Schwarz criterion & -2.701 \\
\hline F-statistic (Prob) & $3.682(0.008)$ & Hannan-Quinn criter. & -3.064 \\
\hline
\end{tabular}

Table 3: Long Run Co-efficients of ARDL (2, 1, 0, 0, 0, 2) Model.

\begin{tabular}{|c|c|c|c|c|}
\hline \multicolumn{3}{|c|}{ Dependent Variable: LNGSDP_AGRI } \\
\hline Variable & Coefficient & Std. Error & t-Statistic & -5.043 \\
\hline LNAGRIEXP & -1.202 & 0.238 & 2.076 \\
\hline LNEDU & 0.608 & 0.293 & 0.0001 \\
\hline LNHEALTH & 0.104 & 0.366 & 0.285 \\
\hline LNRUDEV & 0.548 & 0.116 & 4.714 \\
\hline LNTRANS & 0.691 & 0.328 & 0.0002 \\
\hline
\end{tabular}


The negative coefficient of 1.20 shows that one percent increase in expenditure on agriculture and allied activities leads to over 1.2 percent decrease in agriculture output and this is in line with the study by [10-12] and contradicts the study by [6-8]. The negative relationship is due to the fact that public expenditure through agriculture and allied activities comprise of other expenditure like Animal Husbandry, Dairy Development, Fisheries, Forestry and Wild Life (in addition to expenditure through Crop Husbandry, Soil and Water Conservation, Agricultural Research and Education) which do not contribute to the increase of agricultural GSDP directly. Expenditure on education is another significant factor for agricultural output in Meghalaya and that supports the studies by $[24,25]$. At $10 \%$ level of significance the effect of public educational expenditure on agriculture output is positive with a coefficient of 0.60 , which indicates that one percent increase in educational expenditure would increase agricultural output by 0.6 percent.

According to [26] farmers who are more educated are in a better position to adopt improved technologies and can also influence adoption by other farmers. However, it is also important to note that improvement in human capital can have a negative impact on overall agricultural production and productivity when it promotes off-farm employment opportunities and exit options out of agriculture to the extent that it reduces the knowledge and skills of those left on the farm. Public expenditure in health however does not significantly affect agriculture output which contradicts the study by although its relationship is positive. Public expenditure in various rural development schemes is another variable that affect agricultural output significantly and supports the study of [27]. The coefficient of 0.54 reveals that one percent increase in public expenditure through rural development would increase agricultural output by over 0.5 percent. Various rural development schemes help raising agricultural productivity that in turn raises agricultural wage and reduce food prices and more importantly reduce rural poverty. Public expenditure in transportation also significantly affects agricultural output, which is in line with the studies of $[28,29]$ One percent increase in public expenditure in transportation raises agricultural output by 0.7 percent. Previous studies also stated that good transportation facilitate easy transport of fertilizer, good seeds; improve agricultural equipments and pesticides at required time for the production of crops. It also facilitates diversion from food crops to commercial crops and good transportation also open up opportunities for the cultivator to sell their produce at a higher price in various urban markets. Good transportation helps bankers to easily establish rural branches and extend financial services to farmers. A decent transport and communication framework likewise helps farming indirectly by connecting isolated villages and promoting a sense of awakening. Other rural enterprises like dairy farming, bee keeping, poultry farming, and sericulture etc. can be adopted as subsidiary enterprises to augment their income in addition to farming. Table 4 shows the results of the Error Correction Representation of the selected ARDL Model. Results show that in the short run, public expenditure through rural development programmes is highly significant and coefficient of 0.15 signifies that if rural development expenditure is increased by one percent, GSDP of agriculture is increased by 1.5 percent. Public expenditure in agriculture and allied sector is the next significant variable with a coefficient of -0.18 which indicates that a percentage increase in agriculture and allied sector expenditure would decrease GSDP Agriculture by 1.8 percent. Public expenditure in education is also significant with a coefficient of 0.17 which implies that if education expenditure is increased by 1 percent, the GSDP of agriculture is expected to increase by 1.7 percent. Finally, coefficient of public expenditure in transport and communication lagged one year is significant and negative. The results show that the error correction term ect $(-1)$ represents the speed of adjustment from short run deviation to its long-run equilibrium with a negative shock and statistically significant coefficient at $1 \%$ level confirms the existence of stable long-run relationship. The Error Correction Term of -0.279 implies that $27.9 \%$ of disequilibrium from the previous year's shock converges back to the long-run equilibrium in the current year.

Table 4: Error Correction Representation of the Selected ARDL (2, $1,0,0,2)$.

\begin{tabular}{|c|c|c|c|c|}
\hline \multicolumn{5}{|c|}{ Dependent Variable: LNGSDPAGRI } \\
\hline Variable & Coefficient & $\begin{array}{c}\text { Std. } \\
\text { Error }\end{array}$ & t-Statistic & Prob. \\
\hline$\Delta$ (LNGSDPAGRI(-1)) & -0.522 & 0.132 & -4.004 & 0.0009 \\
\hline$\Delta$ (LNAGRIEXP) & -0.183 & 0.082 & -2.231 & 0.0395 \\
\hline$\Delta$ (LNEDU) & 0.170 & 0.077 & 2.198 & 0.0420 \\
\hline$\Delta$ (LNHEALTH) & 0.029 & 0.105 & 0.278 & 0.7846 \\
\hline$\Delta$ (LNRUDEV) & 0.152 & 0.043 & 3.527 & 0.0026 \\
\hline$\Delta$ (LNTRANS) & 0.028 & 0.064 & 0.442 & 0.6640 \\
\hline$\Delta$ (LNTRANS(-1)) & -0.102 & 0.059 & -1.739 & 0.1000 \\
\hline \multicolumn{6}{|c|}{ ECM(-1) } & -0.279 & 0.062 & -4.458 & 0.0003 \\
\hline Cointeq = LNGSDPAGRI - (-1.2019*LNAGRIEXP + $0.6080 *$ LNEDU + \\
\hline $0.1043 *$ LNHEALTH + $0.5476 *$ LNRUDEV + 0.6906*LNTRANS + \\
4
\end{tabular}

\section{Diagnostic Tests}

To examine the stability of short-run and long-run coefficients, the cumulative sum of recursive residuals (CUSUM) and cumulative sum of squares of recursive residuals (CUSUMQ) stability tests for the AIC-based error correction models is performed. CUSUM and CUSUMQ plots are depicted in Figure 4(a) and Figure 4(b) respectively. Both the plots statistic confirmed within the $5 \%$ critical bounds of parameter stability. The straight lines in the plots represent critical bounds at $5 \%$ significance level. Therefore, we can conclude that the model is structurally stable. 


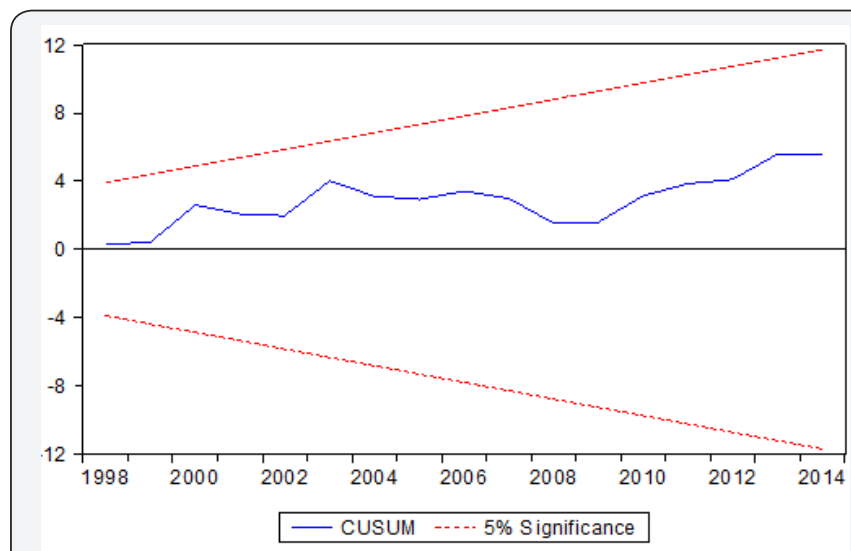

Figure 4 (a): Plot of Cumulative Sum of Recursive Residuals (CUSUM).

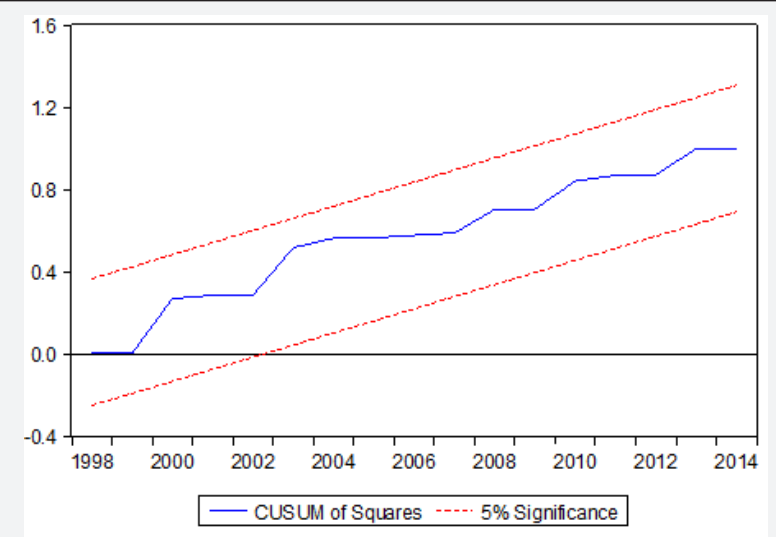

Figure 4 (b): Plot of Cumulative Sum of Squares of Recursive Residuals (CUSUMQ).

\section{Normality Tests}

$\mathrm{H}_{0}$ : Residuals are normally distributed; $\mathrm{H}_{1}$ : Residuals are not normally distributed

Jarque-Bera $=0.365 ; \mathrm{p}=0.833$. Here $\mathrm{H}_{0}$ cannot be rejected, means the residuals are normally distributed.

\section{Breusch-Godfrey Serial Correlation LM Test}

$\mathrm{H}_{0}$ : Residuals are not serially correlated; $\mathrm{H}_{1}$ : Residuals are serially correlated

Obs* R-squared $=5.286 ; \mathrm{p}=0.071$. Therefore $\mathrm{H}_{0}$ cannot be rejected and it is accepted that residuals are not serially correlated.

Hetero skedasticity Test Breusch Pagan-Godfrey

$\mathrm{H}_{0}=$ Residuals are not hetero scedastic; $\mathrm{H}_{1}$ : Residuals are hetero scedastic Obs* R-squared=7.936; $\mathrm{p}=0.635$. Here also residuals are found to be homo scedastic. From the diagnostic tests of the model, it is observed that residuals are normally distributed, not serially correlated and is homo scedastic and the model is stable. Thus the model pass the standard tests and we can say that the model possess the features or characteristics of a good regression model.

\section{Conclusion and Policy Implications}

This paper tried to examine the impact of public expenditure on agriculture output in Meghalaya. Here ARDL approach to co integration and an error correction representation of the ARDL model have been used due to certain advantages. The result of the Bounds test signifies the presence of a long-run co integrating relationship between the variables in the study. The results reveal that in the long run, the effect of public expenditure through agriculture and allied activities on agricultural output is significant and negative at $1 \%$ level. Expenditure on education is another significant factor and positive on the agricultural output in Meghalaya (in line with the studies by. Public expenditure in healthcare however does not significantly affect agriculture output which contradicts the study by although the coefficient is positive. Public expenditure in rural development affects agriculture output significantly and positively which is in line with the study of [27]. Public transportation expenditure also has a significant and positive effect on agriculture output.

In the light of the findings we can say that various types of Government spending have varied impacts on agricultural output implying potential to improve efficiency of government spending by reallocation among sectors. Governments should take conscious efforts to reduce spending in unproductive sectors but should instead increase their spending in sectors like agriculture, education, transportation and rural development in order to enhance the quantity and quality of agricultural output. Moreover spending in these sectors not only yields high returns to agricultural production, but also has a large impact on poverty reduction since most of the poor still reside in rural areas and their main source of livelihood is agriculture. Government should also take efforts to adopt a monitoring mechanism to ensure that budgetary allocation to various sectors are allocated for what it is intended to assure good result. Government should also take initiative to provide an enabling environment that will encourage young school dropouts to take farming as a profitable profession. But this can be attained through the provision of social facility in the rural areas where most of the farming activities take place. Finally, it can be concluded that increase and monitored budgetary allocation to various sectors may contribute significantly to agriculture and it is one of the effective instruments of achieving improvement in agricultural output that has remained an important challenge to the government of Meghalaya.

\section{References}

1. Djurovic Todorovic J, Djordjevi M (2009) The Importance of Public Expenditure Management in Modern Budget Systems. Economics and Organization 6(3): 281- 294.

2. Nurudeen A, Usman A (2010) Government Expenditure and Economic Growth In Nigeria, 1970-2008: A Disaggregated Analysis. Business and Economics Journal, BEJ-4: 1-11.

3. Ewubare D B, Eyitope J A (2015) The Effects of Public Expenditure on Agricultural Production Output in Nigeria. Journal of Research in Humanities and Social Science 3(11): 07-23. 
4. Olomola A, Mogues T, Olofinbiyi T, Nwoko C, Udoh E, et al. (2014) Analysis of Agricultural Public Expenditures in Nigeria Examination at the Federal, State, and Local Government Levels. IFPRI Discussion Paper 01395, Development Strategy and Governance Division, International Food Policy Research Institute.

5. Binswanger HP, Khandker S R, Rosenzweig M R (1993) How Infrastructure and Financial Institutions Affect Agricultural Output and Investment in India. Journal of Development Economics 41(2): 337-366.

6. Selvaraj K N (1993) Impact of Government Expenditure on Agriculture and Performance of Agricultural Sector in India. Bangladesh J Agric Econs XVI(2): 37- 49 .

7. Iganiga B O, Unemhilin D O (2011) The Impact of Federal Government Agricultural Expenditure on Agricultural Output in Nigeria. Journal of Economics 2(2): 81-88.

8. Obi K O, Obayori J B (2016) Dynamic Effect of Government Spending On Agricultural Output in Nigeria. The International Journal of Social Sciences and Humanities Invention 3(2): 1880-1886.

9. Udoh E (2011) An examination of public expenditure, private investment and agricultural sector growth in Nigeria: Bounds Testing Approach. International Journal of Business and Social Science 2(13): 285-292.

10. Yusuf W A, Adesope A A A, Okoruwa V 0 (2013) An Analysis of Federal Government Expenditure and Monetary Policy on Agricultural Output in Nigeria. International Journal of Economics, Finance and Management Sciences 1(6): 310-317.

11. Ani D P, Biam C K, Kantiok M (2014) Patterns and Impact of Public Expenditure on Agriculture: Empirical Evidence from Benue State, Nigeria. Journal of Agricultural \& Food Information 15(4): 311-323.

12. Matthew A, Mordecai B D (2016) The Impact of Public Agricultural Expenditure on Agricultural Output in Nigeria (1981-2014). Asian Journal of Agricultural Extension, Economics \& Sociology 11(2): 1-10.

13. FAO (Food and Agricultural Organization of the United Nations) (2012) The State of Food and Agriculture, Rome, Italy.

14. Adofu I, Abula M, Agama J E (2012) The Effects of Government Budgetary Allocation to Agricultural Output in Nigeria. Sky Journal of Agricultural Research 1(1): 1-5.

15. Okezie A I, Nwosu C, Njoku A C (2013) An assessment of Nigeria expenditure on the agricultural sector: Its relationship with agricultural output (1980 - 2011). Journal of Economics and International Finance 5(5): 177-186.

16. Muftaudeen O O, Hussainatu A(2014) Macroeconomic Policy and Agricultural Output in Nigeria: Implications for Food Security. American Journal of Economics 4(2): 99-113.

This work is licensed under Creative

Commons Attribution 4.0 Licens

DOI: 10.19080/IJESNR.2018.08.555735
17. Wangusi C, Muturi W (2015) Impact of Agricultural Public Spending on Agricultural Productivity: Case Study of Kenya. International Journal of Sciences: Basic and Applied Research 24(4): 180-187.

18. Chandio A A, Jiang Y, Rehman A, Jingdong L (2016). Impact of Government Expenditure on Agricultural Sector and Economic Growth in Pakistan. American-Eurasian J Agric \& Environ Sci 16(8): 14411448.

19. Muraya B W, Ruigu G (2017) Determinants of Agricultural Productivity in Kenya. International Journal of Economics, Commerce and Management 5(4): 159-179.

20. Zirra C T O, Ezie O (2017) Government Fiscal Policy and Agricultural Sector Outputs in Nigeria: Evidence from Fully Modified Ordinary Least Square (FMOLS). Journal of Research in Business, Economics and Management (JRBEM) 8(3): 1434-1443.

21. Pesaran M H, Shin Y (1999) An autoregressive distributed lag modeling approach to cointegration analysis. In Storm S (ed) Econometrics and Economic Theory in 20th Century: The Ragnar Frisch Centennial Symposium Cambridge: Cambridge University Press, England.

22. Pesaran M H, Shin Y, Smith R J (2001) Bounds testing approaches to the analysis of level relationships. Journal of Applied Econometrics 16: 289-326.

23. Pudasaini S P (1983) The Effects of Education in Agriculture: Evidence from Nepal. American Journal of Agricultural Economics 65: 509- 515.

24. Weir S (1999) The Effects of Education on Farmer Productivity in Rural Ethiopia.WPS99-7, Centre for the Study of African Economies. Department of Economics, University of Oxford, United Kingdom.

25. Fan S, Neetha Rao (2003) Public Spending in Developing Countries: Trends, Determination, and Impact. EPTD Discussion Paper No. 99. International Food Policy Research Institute, Washington, D.C. U.S.A.

26. Benin S, Mogues T, Cudjoe G, Josee Randriamamonjy J (2009) Public Expenditures And Agricultural Productivity Growth In Ghana. Contributed Paper, IAAE, Beijing, International Food Policy Research Institute, Beijing, China.

27. Llanto G M (2012) The Impact of Infrastructure on Agricultural Productivity. Discussion Paper Series No. 2012-12, Philippine Institute for Development Studies, Philippines.

28. Tunde A M, Adeniyi E E (2012) Impact of Road Transport On Agricultural Development: A Nigerian Example. Ethiopian Journal of Environmental Studies and Management 5(3): 232-238.

29. Lokesha M N, Mahesha M (2016) Impact of Road Infrastructure on Agricultural Development and Rural Road Infrastructure development programmes in India. International Journal of Humanities and Social Science Invention 5(11): 1-7.

\begin{tabular}{l} 
Your next submission with Juniper Publishers \\
will reach you the below assets \\
- Quality Editorial service \\
- Swift Peer Review \\
- Reprints availability \\
- E-prints Service \\
- Manuscript Podcast for convenient understanding \\
- Global attainment for your research \\
- Manuscript accessibility in different formats \\
( Pdf, E-pub, Full Text, Audio) \\
- Unceasing customer service \\
Track the below URL for one-step submission \\
https://juniperpublishers.com/online-submission.php \\
\hline
\end{tabular}

